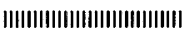

論 文

|||||||||||||||||||||||||||||||||

\title{
長・短繊維からなる混紡スライバの構造解析
}

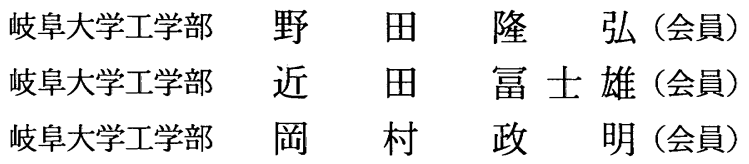

\section{Structural Analysis of Blended Sliver Composed of Long and Short Fibers}

\author{
Takahiro Noda, Fujio Konda and Masaaki Okamura \\ Faculty of Engineering, Gifu University, Yanagido, Gifu
}

\begin{abstract}
The Fiber leading end density in the blended sliver composed of long and short fibers was measured and crosssectional number of fibers was obtained by using sliver diagram. The sliver structure was analyzed along the sliver axis.

Subsequently, the influence of various drafting conditions on the sliver structure was also examined.

The results obtained are as follows:

(1) Variations in the fiber leading end density of short and long fibers in the blended sliver showed a similar tendency along the sliver axis. In all regions along the sliver axis, variation in the fiber leading end density of the short fiber component is larger than that of the long fiber component.

(2) In the blended sliver composed of long and short fibers, there are a large number of short fibers in the region where the sliver gets thicker. On the other hand, there are a large number of long fibers in the region where it gets thinner. This tendency gets more and more noticable with an increase in draft ratio and roller gauge.

(3) The correlation coefficient of the cross-sectional number of long and short fibers increases in accordance with draft ratio and roller gauge. The phase of short fibers advances a little more than that of long fibers.

(Received September 1, 1994)

(Accepted for Publication November 9, 1994)

\section{摘要}

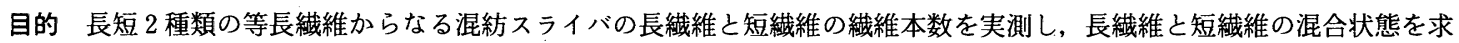
める.これによりスライバの構造解析を行い，混紡スライバの長さ方向の構造を明らかにすることを目的とする.

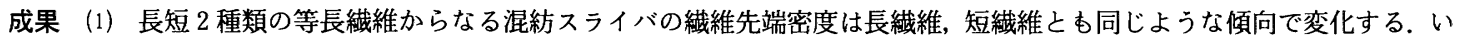
ずれの位置においても，短瀻維の変化が長繊維より大きい.

(2) スライバの太い部分に短䋡維, 細い部分に長繊維が多く存在する。この傾向はドラフト比の増大により, 一層顕著とな る.

(3) 種々のドラフト条件において, 長繊維と短繊維の断面繊維本数の相互相関係数の極大值はほぼ同じである. 短織維の位相 が長織維より少し進んでいる.

\section{1. 緒 言}

消費者の多様なニーズ，製品の高付加価値化およ び各種の用途開発に対応するために紡績分野では繊 維長, 繊維原料, 繊度なぞ著しく特性の異なる素材

(平成 6 年 9 月 1 日受理) (平成 6 年11月 9 日審査終了) の組み合わせによる様々な混紡が盛んに行われてい る. 混紡の主目的は各㵶維を均一に混合し, 高品質 の糸を製造することである。しかし，混紡は多成分 系のために混合むらの発生を避けることができず, 後工程において種々の課題を引き起こしている.
\end{abstract}


これまで, 混合むらの測定, 評価に関する研究は 糸を対象として多くの報告がなされているが，緘維 本数の多いスライバを対象とした報告はあまりなさ れていない，そのなかで石川ら"はギルスライバの 断面㵶維本数から混紡むらを混紡率の変動率で表 し，大沢ら ${ }^{2)}$ は練条スライバの断面における緎維の 分散状態から混紡率の変動率を求めている. また, M. Hannah ${ }^{3)}$ は梳毛英式前紡でトップスライバの混 合効果の向上に関する理論的研究を行っている.

しかし，これらはいずれも紡出後の繊維束におけ る混合むらの理論的研究, 評価が中心であり, ドラ フトプロセスの解析により, 紡出スライバの構造解 析を行い, 混合むらの発生機構を明らかにする試み はなされていない。

筆者らは前報)で混合むらの発生機構を明らかに することを目的に, 繊維長の異なる長短 2 種類の等 長絾維からなる混紡スライバのドラフトプロセスを 解析し，プロセスを構成する要素間の関係を明らか にした．この関係より供給スライバの太さから計算 により紡出スライバの太さを求めた. その結果, ス ライバの太い部分に短繊維が, 細い部分には長繊維 が多く存在し, 混紡スライバ全体の断面繊維本数の 変動は短繊維のそれに大きく依存していることを示 唆した.

本報は混紡スライバの長さ方向の構造を明らかに することを目的とした. 長短 2 種類の等長緘維から なる混紡スライバの長繊維, 短繊維の本数をスライ バの長さ方向に沿って実測し, 㵶維先端密度を求め た. 繊維先端密度の変化から断面繊維本数の変化を スライバダイヤグラムにより計算し, 長繊維と短緎 維との混合状態を求め, スライバの長さ方向の構造 解析を行った。 また, 種々のドラフト条件がスライ バの構造に及ぼす影響についても検討した。

\section{2. スライバの構造解析方法}

混紡スライバの長さ方向に長繊維および短繊維の 繊維本数がごのように変化しているかを知るため に, 繊維先端密度の変化を求めた. スライバ軸上の 微小区間 $\Delta x$ に存在する繊維先端の本数を $\Delta n$ とす ると, 絾維先端密度は $\Delta n / \Delta x$ で表され ${ }^{5)}$, この区間 が繊維長以下の場合には緘維先端密度の変化はスラ イバの断面緘維本数の変化にほとんど影響を及ぼさ ないことが明らかにされている゙

本研究ではコームソー夕を用い, 繊維先端の本数 を実測した。コーム間隔は $6 \mathrm{~mm}$ であるのでこの間
隔が微小区間に相当するとして, 予備実験でコーム 間隔を $6 \mathrm{~mm}, 12 \mathrm{~mm}, 18 \mathrm{~mm}$ の条件で混紡スライバ の繊維先端の本数を実測したところ，いずれのコー ムにおいてす繊維先端密度は, ほぼ同じ変化を示し た. そこで, 計測の煩雑さ, 労力を考慮し, 実験効 率の点からコーム間隔を $18 \mathrm{~mm}$ と決定した。 そこ で区間 $18 \mathrm{~mm}$ に先端のあるすべての繊維を抜き取 り，長繊維と短繊維に分離した。 それぞれの繊維の 重量を測定し, 繊維本数を求め, この区間の繊維先 端密度とした。なお，長繊維，短繊維とあ区間内で は均一に分布していると仮定した．この測定をすべ ての混紡スライバについてスライバ長さ $230 \mathrm{~cm}$, 128区間にわたり行った。

混紡スライバの繊維先端の位置を順に並び替えて 図1(A)のスライバダイヤグラムを得る。位置 $x$ にお

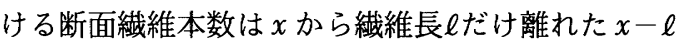
と $x$ との間に先端を持つ繊維の総数である.このよ うに全区間について断面繊維本数を求めることがで きる. 一例を図 1 (B)に示す.

本研究に使用した長短 2 種類の等長䋐維からなる 混紡スライバは長繊維の繊維長 $76 \mathrm{~mm}$, 短繊維の緎 維長 $51 \mathrm{~mm}$ で重量混合率は $50 \%$ ，スライバ番手 $16.5 \mathrm{ktex}$, 両緘維とも繊度 $3 \mathrm{~d}$ のアクリルである.

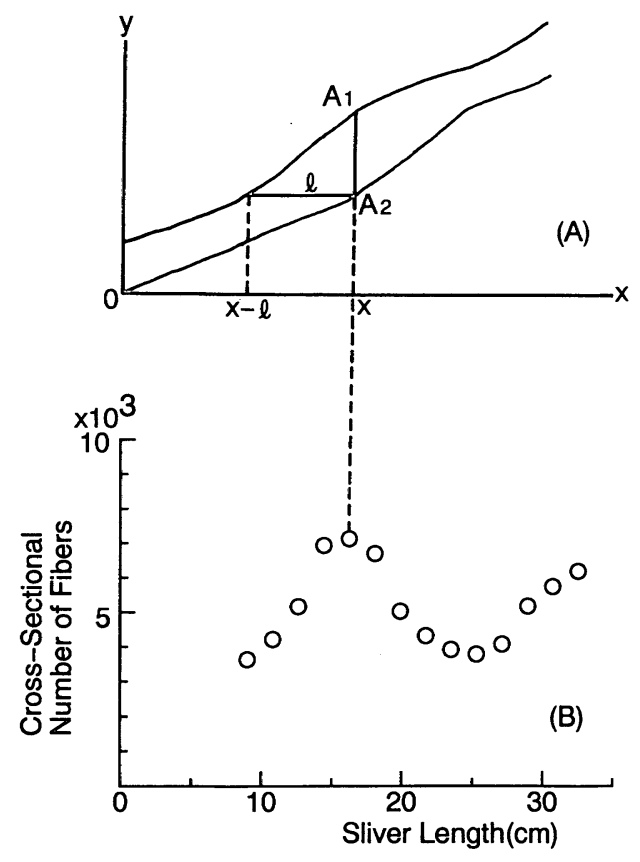

Fig. 1 Sliver diagram and cross-sectional number of fibers:(A), sliver diagram;(B), variation in cross-sectional number of fibers 


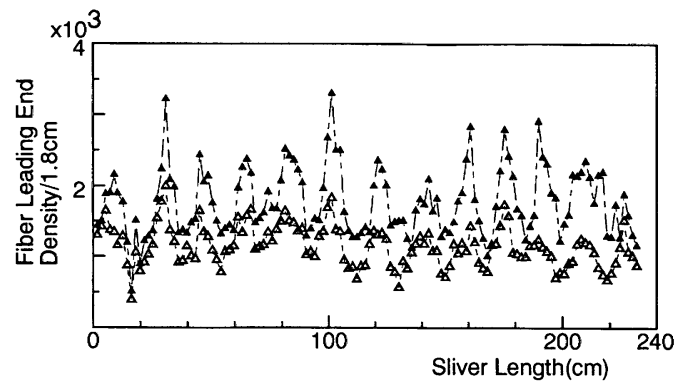

Fig. 2 Variation in fiber leading end density: draft ratio, 6 ; roller gauge, $100 \mathrm{~mm} ; \triangle$, long fiber ; $\boldsymbol{\Delta}$, short fiber

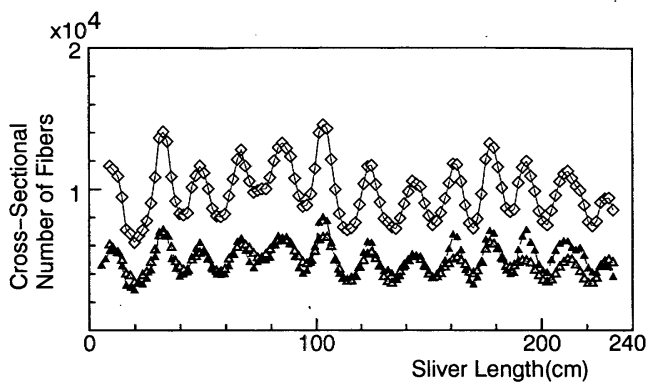

Fig. 3 Variation in cross-sectional number of fibers : draft ratio, 6 ; roller gauge, $100 \mathrm{~mm}$; $\triangle$, long fiber ; $\boldsymbol{\Delta}$, short fiber $\diamond \diamond$, total fiber

この混紡スライバを 2 線式ローラドラフト機でロー ラゲージ $100 \mathrm{~mm}$ に対し，ドラフト比を，3，4，6， 8 と変化させた場合およびドラフト比 3 に対し， 口 ーラゲージを $100,125,150 \mathrm{~mm}$ と変化させた場合 の条件でドラフトを行い, 測定用試料とした.

\section{3. 実験結果亡考察}

\section{1 長さ方向におけるスライバの構造}

前章で記した方法により, 絾維先端密度および断 面繊維本数の变化を求めた。一例を図 2 に示す。こ の図はドラフト比 6 , ローラゲージ $100 \mathrm{~mm}$ の条件 でドラフトしたスライバの繊維先端密度の変化を示 す. 長さ方向において長緘維および短繊維の両繊維 とも同じょうな傾向で変化している. しかし，スラ イバのいずれの位置でも短繊維の繊維先端密度の値 は長繊維より大きい.

図 3 は図 1 の方法により図 2 の繊維先端密度から 求めた断面繊維本数曲線を示す. 測定した長瀻維と 短繊維の繊維本数を全区間について合計すると長繊 維と短繊維の本数比は $1.0: 1.53$ であり, 重量比に 換算して長繊維 $49.3 \%$, 短繊維 $50.7 \%$ と求められ
た。この結果は長繊維と短繊維の全体の重量混合率 （50\%）とほぼ一致している. スライバの長さ方向に おける長繊維と短繊維の断面緘維本数は, ほぼ同じ 周期で変化を繰り返し，短緘維の変化が長繊維より 大きいことを示している，長繊維と短繊維の断面繊 維本数の和はスライバを構成している総緎維の断面 繊維本数であり, 総纎維もほぼ同じ周期で変化して いる. 長繊維, 短緘維, 総緘維の断面緘維本数の変 化を比較すると総繊維の断面繊維本数が極大を示す 位置で短繊維の断面繊維本数は長纎維より多く, 極 小を示す位置では長繊維の方がより多い傾向を示し ている. 山下ら〉は混紡系の断面の太さと混紡率の 相関からむらの起こしやすい成分が混紡系の太い部 分に集まりやすいことを示し，近田ら8 イバの混合むらの解析においてスライバの太い部分 に短い繊維が偏在する傾向のあることを明らかにし ている，本研究はこれらと同様な傾向を示してお り, 前報()の結果とも一致した。

\section{2 ドラフト条件が混紡スライバの構造に及 ぼす影響}

前節で短繊維の断面繊維本数の変化が長繊維より 著しく, スライバの太い部分に短繊維, 細い部分に 長繊維が多く存在する傾向のあることを明らかにし た. 本節ではドラフト条件がこの傾向にどのように 影響するかを検討する.

図 4 はドラフト比と断面瀻維本数の变動係数の関 係を示したものである.いずれのドラフト比であ短 繊維の断面繊維本数の変動係数は長繊維より大き い. ドラフト比の増大により短瀻維の変動係数が増 大していく. 一方, 長緘維の変動係数はドラフト比

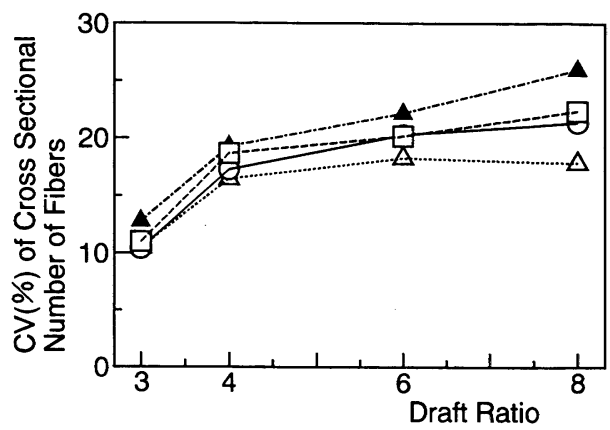

Fig. 4 Influence of draft ratio on coefficient of variation in cross-sectional number of fibers : roller gauge, $100 \mathrm{~mm} ; \triangle$, long fiber ; $\boldsymbol{\Delta}$, short fiber; $\bigcirc$, total fiber; $\square$, irregularity tester 


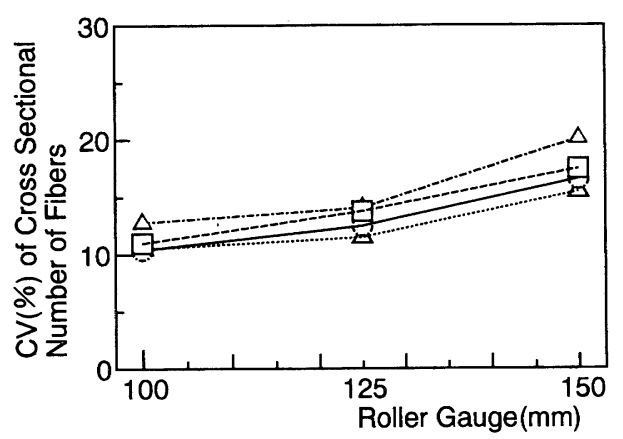

Fig. 5 Influence of roller gauge on coefficient of variation in cross-sectional number of fibers : draft ratio, $3 ; \triangle$, long fiber $\triangle$, short fiber; $\bigcirc$, total fiber; $\square$, irregularity tester

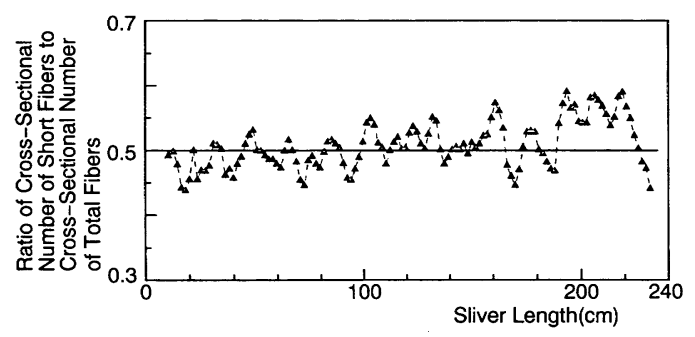

Fig. 6 Variation in ratio of cross-sectional number of short fibers to cross-sectional number of total fibers : draft ratio, 6 ; roller gauge, $100 \mathrm{~mm} ; \Delta$, short fiber

3 から 4 にかけて短緘維と同様に増加するが，ドラ フト比 4 以上ではそれほど変化がみられない，総織 維の変化は短繊維と長繊維の中間に位置しており, むら試験機から得られた太さむらの変動係数とほぼ 同じ傾向を示している.

図 5 はローラゲージが断面繊維本数の変動係数に 及ぼす影響を調べたものである，短繊維の変動係数 はいずれのローラゲージであ長繊維より大きい， ロ ーラゲージの増大により, 短繊維, 長繊維ともに変 動係数が増大する傾向がみられる. 総繊維の変動係 数は図 4 と同様, 短繊維と長繊維の中間に存在して おり,むら試験機の結果とほぼ同じ傾向を示してい る.

図 6 は総緎維の断面繊維本数に対する短緎維の断 面繊維本数の比率を示す. 短繊維の断面繊維本数比 率が 0.5 以上の場合は短繊維の断面緘維本数が長繊 維より多く,0.5以下では長繊維が短緘維より多い ことを示す. 図 3 の総繊維の断面緎維本数が極大を 示す位置においては, 図 6 で短㵶維の断面繊維本数

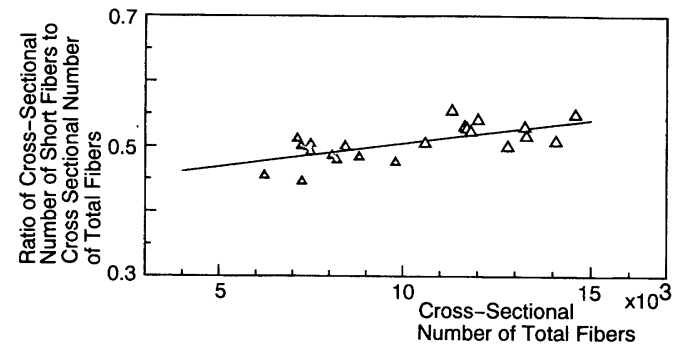

Fig. 7 Relation between cross-sectional number of total fibers and ratio of cross-sectional number of short fibers to cross-sectional number of total fibers : draft ratio, 6 ; roller gauge, $100 \mathrm{~mm} ; \triangle$, maximum value $\triangle$, minimum value

比率が 0.5 以上を示す場合が多く, 逆に極小の位置 では 0.5 以下を示す傾向がみられる.

この傾向を一層明瞭にするために, 図 3 で総繊維 が極大および極小を示した位置で図 6 の短繊維の断 面繊維本数比率を取り出し, 図 7 に示す.この結果 より, 極大值では短繊維の断面繊維本数が多く, 極 小値では長繊維が多いことが明らかである.

回帰分析を行い, 図中に回帰直線を示す. 回帰直 線の傾きである回帰係数の大小が, 太い部分の短緎 維, 細い部分の長繊維の多少を示し, 短繊維および 長織維の存在状態を定量的に比較することができ る. そこでドラフト比, ローラゲージが増大した場 合の長繊維および短繊維の存在状態を明らかにする ために, ドラフトしたすべての混紡スライバの回帰 分析を行い, 回帰係数を求めた.

図 8 にドラフト比と回帰係数の関係を示す. ドラ フト比の増大に伴い, 回帰係数が増大する. 図 9 は ローラゲージと回帰係数の関係を示す. ローラゲー ジの増大に伴い, 回帰係数が増大する.

この結果, ドラフト比, ローラゲージの増大によ り, 混紡スライバの太い部分には短繊維, 細い部分 には長繊維が多く存在する傾向のあることが明らか となった。

\section{3 長緎維と短瀻維の断面䋗維本数の相互相 関}

図 3 において長繊維と短繊維の断面繊維本数曲線 は類似した周期で変化することを明らかにした．そ こで他のドラフト条件における長繊維と短繊維の断 面繊維本数曲線の関係を求める.

図10は各ドラフト比における断面繊維本数の波長 を示す.いずれのドラフト比においても長繊維, 短 


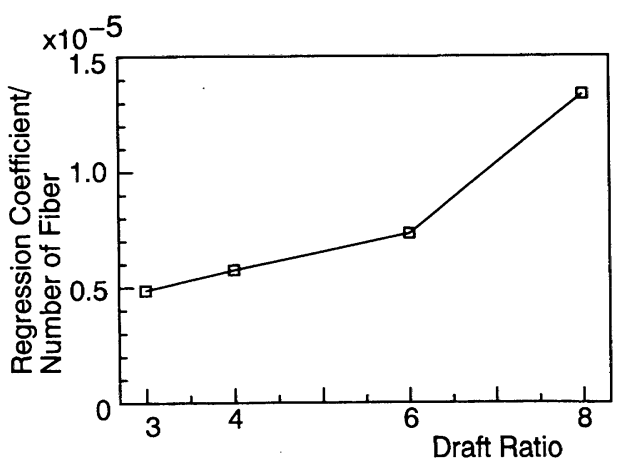

Fig. 8 Relation between draft ratio and regression coefficient : roller gauge, $100 \mathrm{~mm}$

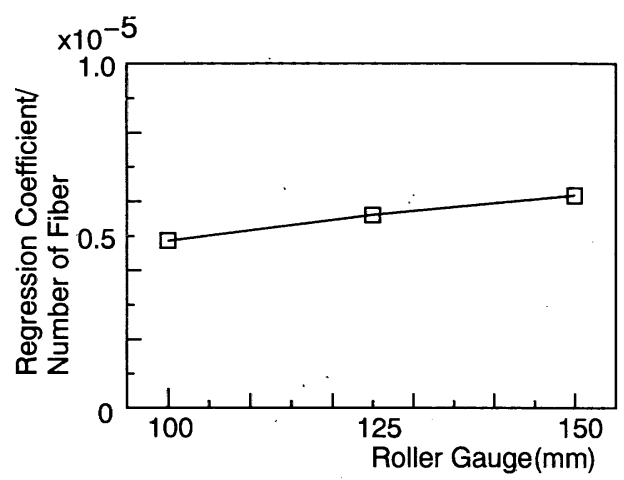

Fig. 9 Relation between roller gauge and regression coefficient : draft ratio, 3

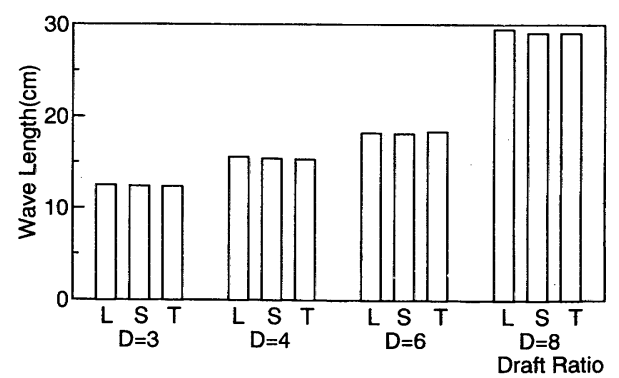

Fig. 10 Effect of draft ratio on wave length : roller gauge, $100 \mathrm{~mm}: \mathrm{L}$, long fiber; $\mathrm{S}$, short fiber $; \mathrm{T}$, total fiber

繊維および総繊維の波長はほぼ同じ値を示し，ドラ フト比の増大に伴い, 各繊維の波長はそれぞれ増加 する.

図11は各ローラゲージにおける断面繊維本数の波 長を示す.いずれのローラゲージにおいても長緎 維, 短繊維および総緘維の波長はほぼ同じ値を示 し, ローラゲージの増大に伴い, 各繊維の波長は増 加する. すなわちドラフト比, ローラゲージの増大

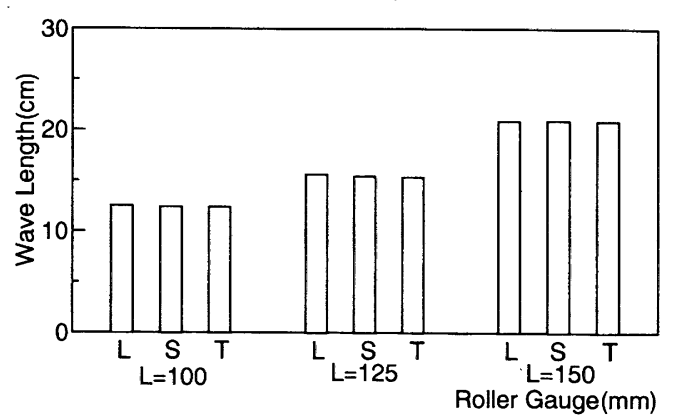

Fig. 11 Effect of roller gauge on wave length : draft ratio, $3: \mathrm{L}$, long fiber ; $\mathrm{S}$, short fiber ; $T$, total fiber

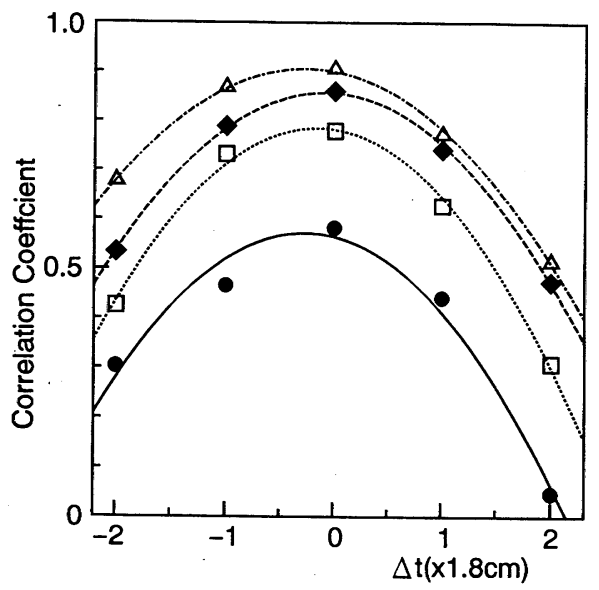

Fig. 12 Cross correlation function between long fibers and short fibers for various. draft ratios : roller gauge, $100 \mathrm{~mm} ; \mathbf{0}, \mathrm{D}=3 ; \square$, $\mathrm{D}=4 ; \diamond, \mathrm{D}=6 ; \triangle, \mathrm{D}=8$

により長繊維, 短繊維の断面緘維本数の波長は増加 傾向を示す.

図 3 を詳細に観察すると長繊維と短繊維の変化に 若干の位相のずれがみられる。 そこで長繊維と短緘 維の断面繊維本数の相互相関関数を求め, 相関の強 さとずれの関係を求めた. 図12は各種のドラフト比 における長織維と短繊維の断面織維本数の相互相関 関数を示す。よこ軸は長繊維と短緘維の断面緘維本 数の長さ方向の区間のずれ量を示し, 負の方向は長 繊維を固定して,ドラフト方向に短繊維をずらした 場合，正の方向はドラフト方向と逆方向に短緘維を ずらした場合である。ドラフト比の増大につれ，相 互相関係数は増大する．また，いずれのドラフト比 においてもドラフト方向に $0 \mathrm{~cm}$ から $1.8 \mathrm{~cm}$ のずれ 量の間に相関係数の極大值を持つ。このことは短緎 維の挙動が長纃維より少し進んでいることを表して 


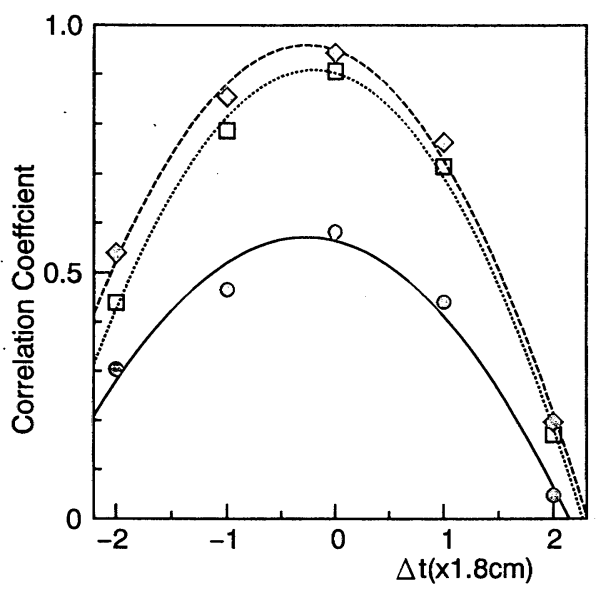

Fig. 13 Cross correlation function between long fibers and shorts fibers for various roller gauges : draft ratio, $3 ; \mathrm{L}=100 ; \square, \mathrm{L}=$ $125 ; \mathrm{L}=150$

いる.

図13は各種のローラゲージにおける長繊維と短繊 維の断面繊維本数の相互相関関数を示す.よこ軸の 関係は図 12 と同じである. ローラゲージの増大につ れ，相互相関係数は増大する．また，いずれのロー ラゲージにおいてもドラフト方向にずれ量が $0 \mathrm{~cm}$ から $1.8 \mathrm{~cm}$ の間に相関係数の極大值を持つ.この ことはいずれのローラゲージにおいても短繊維が長 繊維より少し進んでいることを表している.

ギルスライバにおいて短繊維成分の周期的変化が 長繊維成分よりあ少し進み，位相が少しずれている こと泉が報告されており，本実験においてもこの現 象がローラドラフトでドラフトされたスライバであ 発生していることを明らかにすることができた。

\section{4. 結 言}

混紡スライバの長さ方向の構造を明らかにするこ とを目的に長短 2 種類の等長瀻維からなる混紡スラ イバの長繊維, 短緘維の繊維本数を実測し, 繊維先
端密度を求めた. 緎維先端密度からスライバダイヤ グラムにより, 長繊維, 短繊維の断面繊維本数を計 算し，スライバの長さ方向の構造解析を行った。 そ して種々のドラフト条件がスライバの構造に及ぼす 影響を検討した。

得られた結果をまとめると次のようになる.

(1) 長短 2 種類の等長纎維からなる混紡スライバ の繊維先端密度の変化はスライバの長さ方向に対 し, 長繊維, 短繊維とも同じような傾向を示し, い ずれの位置においても短繊維の変化が長繊維より大 きい.

(2) 長短 2 種類の等長繊維からなる混紡スライバ において, 太い部分では短纎維の断面繊維本数が, 細い部分では長繊維の断面繊維本数が多い.この傾 向はドラフト比, ローラゲージの増大により,一層, 顕著になる。

（3）ドラフト比，ローラゲージの増大により短緎 維の断面繊維本数の変動係数は長緘維のそれより増 加する。

（4）ドラフト比，ローラゲージの増大により長緎 維之短繊維の断面繊維本数の相互相関係数は増大 し，極大值の位置はほぼ同じである．短繊維の位相 が長繊維より少し進んでいる.

\section{参考文献}

1）石川，来栖; 紻維学会研究発表会前刷（1952-6）

2) 大沢, 橋場; 綫維学会綫維特別研究発表会講演前刷（195410)

3) M. Hannah ; J. Text. Inst., 44, T436 (1953)

4) 野田, 岡村, 近田; 縡機誌, 48, T. 39 (1995)

5) 織維工学 (III) 「系の製造・性能及び物性」, p. 173, 日本紻 維機械学会 (昭和62年)

6) 織維工学 (III) 「系の製造・性能及び物性」, p. 214, 日本䋐 維機械学会（昭和62年）

7）山下, 川端, 河合; 繊機誌, 20, T61 (1967-3)

8）近田, 岡村, 黒崎, 渡辺, 安田; 織機誌, 46, T61（19933)

9）近田，岡村，黑畸，野田; 織機誌，46, T179（1993-8） 